\title{
トマト，茄子等の $\mathrm{F}_{1}$ 探種に於ける無蓋交配法*
}

古 谷 春 吉

(東京種苗試驗場)

緒

事變以變，肥料，藥劑其他䟽荣生產資材の著しき減少並に農村特に近郊流荣地に於ける靑 壮年の軍事厂場移動とから，從來の如き品質本位に改良された蔬荣品種の栽培は許され妨實 狀に立至つたのである。玆於てか最近茄子，トマト等に於て强健・管收なる一代雜種の利 用と云ふととが當業者閒に叫ばれるに至つたのである。東京，大阪を始め神奈川，千葉，埼 玉等の農事試驗場園藝部に於ても之等品種の優良なるもの，例人ば茄子に於ける授眞（䓑細

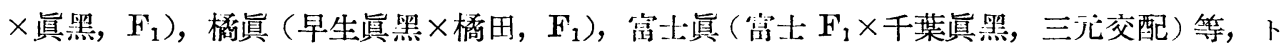
マトに於ける福壽（フルーツメピンク， $\mathrm{F}_{1}$ ) 交配世界一（早生世界一×改良世界一， $\mathrm{F}_{1}$ ) 等 を作出或は試作して，それぞれ管內と獎勵しつ」あるが，遗憾ながら之が探種普原忙朱だ 前途遼遠を思はしむるものがある。

\section{從來の $\mathrm{F}_{1}$ 探種法}

從來各府縣農試園藝部に於ての $\mathrm{F}_{1}$ 探種は主として試驗又は試作の爲に行はれ，從つて其 の方法も多くは實驗室的方法を一步も出てるないのである。

抑々茄子の $\mathrm{F}_{1}$ 利用に就ては今より十數年前郎ち昭和 3,4 年頃埼玉縣農試杮崎技師に上 つて埼交 (巾着 $\times$ 眞黑, $F_{1}$ ), 王交 (白茄 $\times$ 眞黑, $F_{1}$ ) の組合せが作出され, 管內希望者代 配布されをのである。本種は草性强健で作り易く且つ收量多く，農家の自家用品種として相 當の成績を擧げたのであるが，出荷用としては早生眞黑，中性眞黑等には品質の點に於て稍 了抙色があり，殘念ながら疏荣地に於ける大栽培恃見られなかつた。

其の後神奈川縣農試竹內技師によつて只今の蔓這, 橘県が作出され，その强健，豊產なる ことから從來の眞黑系に代るべき優良品種なるととは，早くも東京近縣䟽荣地の當業者によ つて認められ，其後東京並に横演等中央の種苗會社のカタログによつて一般に廣められたの であるが，昭和 15 年 11 月 5 日農林省告示第 460 號による蔬荣種子公定價格附則第 3 項 により, 農事試驗場, 農會又は探種組合に於て利用又は採種する原種又は一代雜種に限り公 定外價格を認めるととに規定されたをめ，一，二の特殊なる種苗會社を除いては一般に $F_{1}$ 種子は扱は好とよなるの止むなきに至つたのである。

次にトマトの $\mathrm{F}_{1}$ 利用に就ては, 昭和 8 年東京府農試中西技師によつてベストメウインジ 一ルの組合せが作出され，段當 2,800 貫の驚異的レコードが發表されたのである。然し本種 は品質劣等なるととから殘念ながら普及を見なかつたが，其後大阪農試伊藤技師によつて只 今の福壽が作出され，その品質と云ひ收量と云ひ斷然優良であるてとから大阪地方と在つて は，トマトは福壽に限るとの聲が高くなつた。東京地方に於ても事變以來肥料，藥劑の不足 から，從來盛んに栽培されてるた世界一トマトの栽培が稍々困難となり，交配世界一の作出 を見るに至つてから，交配トマトの聲價は斷然高くなつたのである。

\footnotetext{
* 本研究の要旨は昭和 18 年 4 月 11,12 日開催第 14 间日本農學會大會部會園藝學會に於て發表
} 


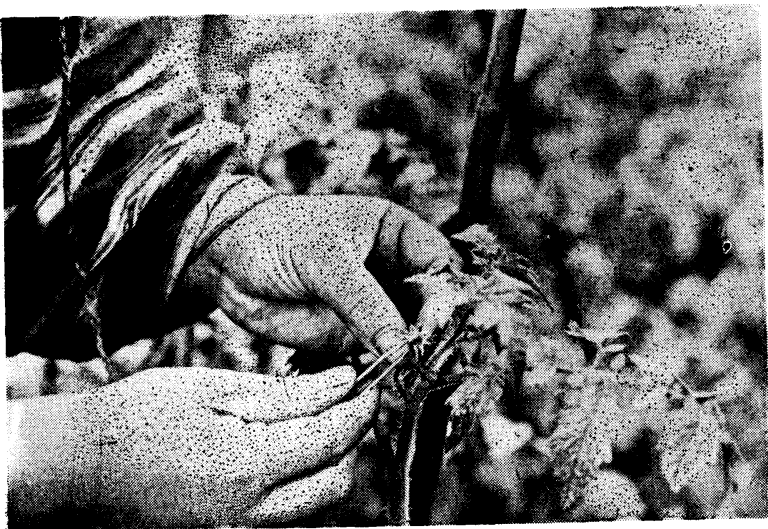

第 1 圖卜マトの除雄作業

そトマト $\mathrm{F}_{1}$ 探種場を設定，涉公谷ふ力子外 5 名の交 配手を養成，創立の最初昭和 9 年飞は中西技師のべ ストを母本とした組合せで，交配の方法も實驗室的 なもので，明日㗛く花蕾2 ケ文前日午後除雄し，他 注鋏み切つてパラフィン紙の袋（全紙 16 枚切）を 掛け，翌朝袋をはずして父本であるウインジールの 花粉を以つて交配せしめ再び袋を掛けると云ふ方法 であつた。

專門家は，既行承知のととと思ふが，ベストの結 果㚙性は，圖に示す通り，1 本の花梗の左右に並ん で 3〜4 段位蕾をつけるものである。

其刀最初㕬くべき㔨2 ケ丈を殘して他汢全部切り

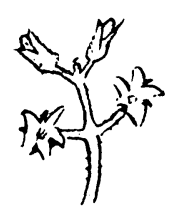

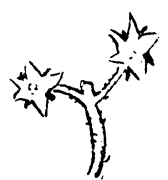

第3 圖

結果替性を示寸說明圖

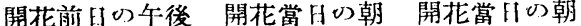
除婎前花房

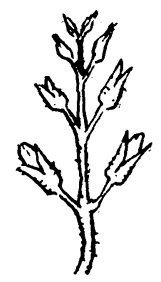

尖るのであるから，交配用母本泣，極度の摘花 の惡影響を受けアブノーマルを生青をなし，そ の後の受精が惡くなつて，僅か 2 升か3外の $\mathrm{F}_{1}$ 種子を得ることに相當な困難をしたもので ある。

其後袋を大きくして 2 ケ宛 2 日に渡つて除雄 並に交配するやう 4 花蕾を殘して袋脚するてと にしてから汁母本の生育も生常であつたが，其 後事變勃發と共飞舶來の上質パラフィン紙の入 手困難之なり，勞少不足し勝となつたので， 


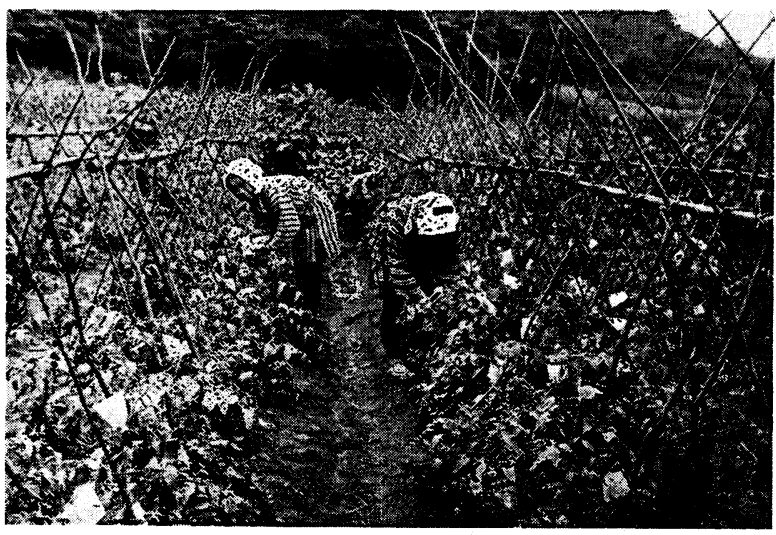

第 4 圖 4 花蕾を入れて袋掛をした時代

何とかして之を克服して行く方 法汢をいものかと交配围場飞立 つて朝夕思案の未，今日の無䒸 交配を考察するに至つたのであ る。

節ち全交配围場にて，明日倁 くべき花蕾汢全部除雄し 1 蕾を も目殘をき事を期して，袋掛を 徹廢したのである。

翋日開花飞當つて，交配围場 に花粉を出すべき雄蕗沈 1 本も ないのであるから袋脚がしてな

\section{くとも差支へない譯である。}

但し，此の無蓋交配飞當つて法隣接闱場は吻論のて子出來待狆ば 1〜2 町位以內に父本以 外の品種の栽培を絕對飞禁止しなければなら䒚い。

\section{無蓋交配の特微}

不可能を可能とし $\mathbf{F}_{1}$ 探種の實用化を實現せしめた本探種法は，從來の袋掛交配採種法 （實驗室的方法）に比較して次の如き特微を舉げるてとが出來る。

1. 凟材を不要とする

パラフィン紙並に止金等の交配用資材を用ひずに澵むとと，之等の金額汢微々たるもので あるが，現在交配に用ひる良質（航來）のパラフィン紙は入手不可能である。袋をはる爲の

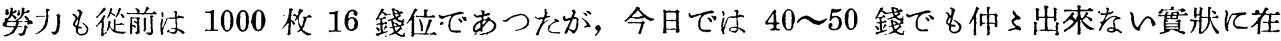
る。

\section{2. 交配勞力を節約するてとが出來る}

袋を脚けをり外したり又脚けをりするととは，著しく交配作業を鈍らせるものである。 無蓋交配であれば，交配作業の如き沙從來の $1 / 5$ の時閒も要しない，郎ち 1 反步 30 分も あれば十分である。

除雄後の袋掛でも，單飞除雄 作業のみを續けることの出來る 埸合沈，1花房每にいちいち袋 脚をしててるる埸合に比して $1 / 2$ 位の勞ノで流むものである。

郎ち全過程を通算して袋㧗を 省略することによつて交配勞ノ を大略 $1 / 3$ に節約するととが出 來る。

從來 1 反步 3 人を要したもの が，本法汇よると一等交配手で あれ代 1 这步 1 人で受持ち，大

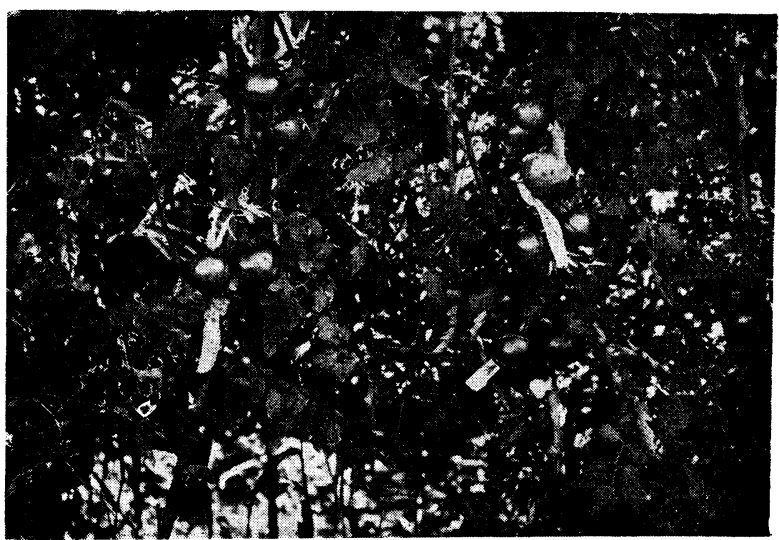

第 5 圖 實驗室的な交配法による探種用種果 品種 ベストオブオール 


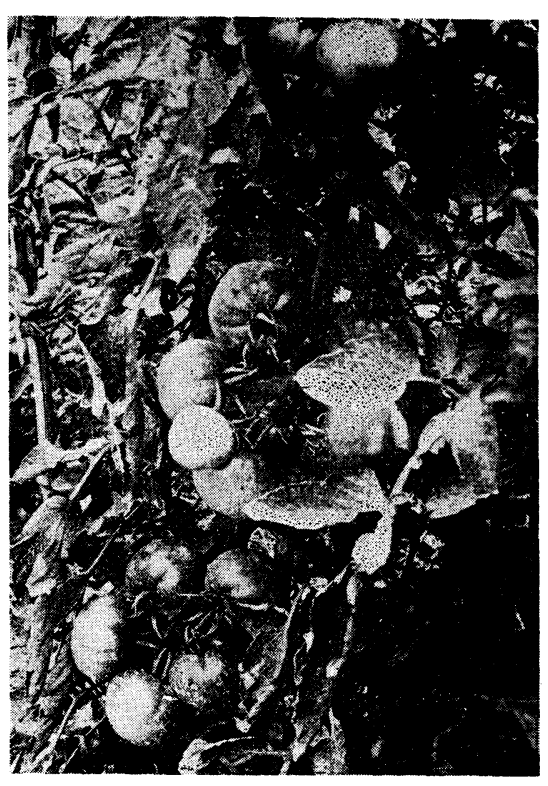

第 6 圆 無蓋艾配による探種用種 果 品種 早生世界一

體 1 ケ月間と交配作業を完了するととが出來るや うになつたのである。

3. 段賞探種量をを堆大せしむること

反當採種量汢，甘本となるべき品種によつて違 ふから一概に汢言へをいが，福壽又汢交配世界一 の場合にて反當 5 斗の探種量を昨年 (昭和 17 年) 得て居るから，一般固定種の探種量飞劣らぬまで に槽ぎつけた譯である。

交配探種㳉，父本のために 1 割队外を割き，交 配作業の都合。第2花房より交配手の肩までの高 さで交配を中止するのであるが，人江を以つて適 期飞交配するてとによつて種子の步止汢良くなる 譯である。

交配に要する費用は，交配手の勞うだけである が，一等交配手段當 1 人 30 日閒， 1 日 2 圓とじ て 60 圓，1 外當りの交配工賃江 1 圓 20 錢とな る譯である。

交配手さへ飬成出來れば，步止の惡い“世界 一”を採種するより蜜ろ此の方法で $\mathrm{F}_{1}$ を探種するととの方が原價計算より見れ壮遙に安く つく譯である。

但し，一般固定種の採種に當り，䒕成沬生果として販賣し，市價の下落し且つ步止のよく なつた中〜未成果（但し種子としでは劣惡である）を採種する場合，或は加工:用トマトの副 產物としての種子を利用すると云ふが如を一般種苗界のありふれた探種法に比較すれば， $\mathrm{F}_{1}$ 探種法斯る最高技術を發揮してる向且現在の公定價格であるならば相當困難であることを覺 悟しなければならない。

此の意味に於て都市郊外の疏荣圈を持つ府縣農事試驗場に於て當該係官が自らのり出して

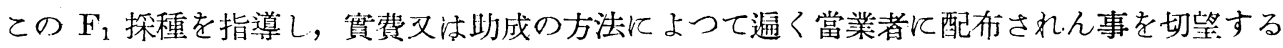
次第である。

\section{茄子に於ける無蓋交配法}

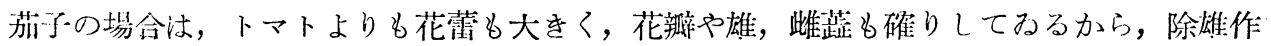
業汁著しく滥單である。

而も第二，第三番花（俗飞云ふ天科成）法必ずと云つてよい位とまるものであるから，交 配ひ機會を逸さぬやうにすれば交配勞うは極めて少く，最盛期反當 1 人，10 日〜 14 日で完 了する。

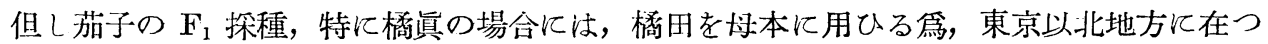
て㳉，6月中に交配を終るやうに設計しなければ，秋になつて朝晚の冷载のため種果の稔實 惡しく, 完熟に先立つて炭疽病が發生し, 之は石灰ボルドー液位で注仲々喰ひ止められぬも のである。

但し，6 月中下旬は採種围擔當農家にとつても極めて多忙なる季節であるから，靑年學校 


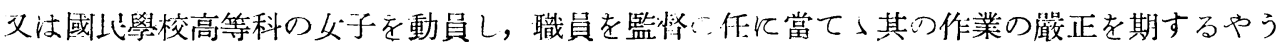
にするてとが最も手近であり，然も純正なる種子の採種上有效であらうかと思ふ。

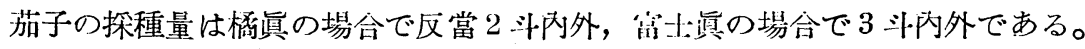

\section{東亞共榮圈內に於けるトマト，茄子 $\mathrm{F}_{1}$ の馨價と內地に於ける $\mathrm{F}_{1}$ 探種の將來}

京濱，阪神等の大都市近郊の疏荣地㳊於けるトマト，茄子の $\mathrm{F}_{1}$ 利用沈色々な意味で益々 盛んになつて來る事であらうし，月つ监んならしむるやうに適賞なる處置を構じなければな らぬとと汁言ふまでもない事である。

單に內地のみでなく, 氣候, 土質の恐い北方大陸に於ても, 或㳉高溫多濕でスコールに惱 まされる南方共筑圈に於ても，前記ベストを使つを組合せの如き强健豐產をる $F_{1}$ 種子を內 地より供給することは，長期戰を勝ち拔く上にも，共笑圈を建設する上にも極訬切切な事 であり，低き印度と低き經濟生活とに湍いでるる東亞農業諸均族に，氣候，士質其他環境及 び農業の經營並に技術の卓越せる日本內地より優良種苗を供給するてとは，今日我が皇國農 此に與へられを名譽ある義務であると言はなければならない。

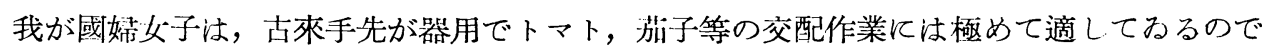
ある。特に前記群馬縣利根郡の如き山間部採種地帶に於て, 冬季閒炭燒の相手位をし, 夏季 比較的農閑である娘達法, 視力强く根氣よく $\mathrm{F}_{1}$ 探種作業に好適すると共に農家經濟の上か ら觀ても蒇に好都合な譯である。

本論文が單なる $\mathrm{F}_{1}$ 探種技術としてのみでなく，將來日本內地の採種園藝をしてけ覺まし く發展せしむる動機ともならば，等者の幸之に過ぐる汢ないのである。 